Sylvie Gerber $\cdot$ Jean-Michel Rozet $\cdot$ Shin-Ichiro Takezawa $\cdot$ Luisa Coutinho dos Santos $\cdot$ Lucilia Lopes Olivier Gribouval · Clotilde Penet · Isabelle Perrault · Dominique Ducroq • Eric Souied · Marc Jeanpierre Serge Romana · Jean Frézal · Fernando Ferraz · Ruth Yu-Umesono · Arnold Munnich · Josseline Kaplan

\title{
The photoreceptor cell-specific nuclear receptor gene (PNR) accounts for retinitis pigmentosa in the Crypto-Jews from Portugal (Marranos), survivors from the Spanish Inquisition
}

Received: 2 May 2000 / Accepted: 21 June 2000 / Published online: 16 August 2000

(C) Springer-Verlag 2000

\begin{abstract}
The last Crypto-Jews (Marranos) are the survivors of Spanish Jews who were persecuted in the late fifteenth century, escaped to Portugal and were forced to convert to save their lives. Isolated groups still exist in mountainous areas such as Belmonte in the Beira-Baixa province of Portugal. We report here the genetic study of a highly consanguineous endogamic population of CryptoJews of Belmonte affected with autosomal recessive retinitis pigmentosa (RP). A genome-wide search for homozygosity allowed us to localize the disease gene to chromosome $15 \mathrm{q} 22-\mathrm{q} 24 \quad(\mathrm{Zmax}=2.95$ at $\theta=0$ at the D15S131 locus). Interestingly, the photoreceptor cell-specific nuclear receptor $(P N R)$ gene, the expression of which is restricted to the outer nuclear layer of retinal photoreceptor cells, was found to map to the YAC contig encompassing the disease locus. A search for mutations allowed us to ascribe the RP of Crypto-Jews of Belmonte to a homozygous missense mutation in the PNR gene. Preliminary haplotype studies support the view that this mutation is relatively ancient but probably occurred after the population settled in Belmonte.
\end{abstract}

S. Gerber · J. M. Rozet · O. Gribouval · C. Penet · I. Perrault D. Ducroq · E. Souied - S. Romana - J. Frézal · A. Munnich J. Kaplan (困)

Unité de Recherches sur les Handicaps Génétiques de l'Enfant, INSERM U393, Hôpital Necker, Paris, France e-mail: kaplan@necker.fr,

Tel.: +33-1-44495156, Fax: +33-1-47348514

S.-I. Takezawa $\cdot$ R. Yu-Umesono

Graduate School for Biostudies, Kyoto, Japan

L. Coutinho dos Santos · L. Lopes

Serviço de Oftalmologia, Hospital Dos Capuchos, Lisboa, Portugal

M. Jeanpierre

INSERM U129 and Service de Biochimie

et Génétique Moléculaire, Hôpital Cochin, Paris, France

F. Ferraz

Serviço de Genética, Hospital Dona Estefânia, Lisboa, Portugal

\section{Introduction}

In the late fifteenth century, the golden age of Sephardic Jewry in the Iberian peninsula came to an end at time of the Spanish Inquisition in 1492, when Jews were offered conversion or expulsion. Many chose to leave Spain but others stayed behind. Some Jews escaped from Spain to Portugal in 1492 only to be trapped later, in 1497, when the expulsion was instituted there as well. Many were forced to convert to save their lives. Large numbers of middle class Jews outwardly took on Christianity to avoid the laws, while secretly practicing Judaism despite the danger of Inquisition punishment. Therefore, they were often considered as faithless in their Christian conversion, rousing old anti-Semitic prejudices and, thus, were called "Marranos", meaning "pigs" in the Castillan language of the 15th century. Converted Jews never accepted this name and referred to themselves as "Crypto-Jews".

These Crypto-Jews still exist in isolated pockets on the Iberian peninsula, in mountainous areas such as the mountain town of Belmonte in the Beira-Baixa province of Portugal (Fig. 1). Their existence came to light in 1917 through the discoveries of Samuel Schwartz, a PolishJewish mining engineer, who vainly sought for remnants of the Belmonte synagogue of 1297. Five centuries after the Inquisition, the last Crypto-Jewish community took a fascinating look at the village of Belmonte, Portugal. Its rites and prayers are an amalgam of Christianity and bits of Judaism tenaciously preserved through the ages, a tradition that bears the scars of history distorted by clandestine practice and couched in symbols of fear. In order to secretly preserve their residual Jewish practices over the centuries, the Crypto-Jews of Belmonte were forced to practice endogamy. In the absence of Rabbi, religious books, synagogue or Hebraic education, the Jewish liturgy was orally transmitted from one generation to the other, essentially by females (Yerushalmi et al. 1992). The high rate of parental consanguinity in this community led to the occurrence of an autosomal recessive form of retinitis pigmentosa (RP; Fig. 2). RP is a heterogeneous group of in- 
B
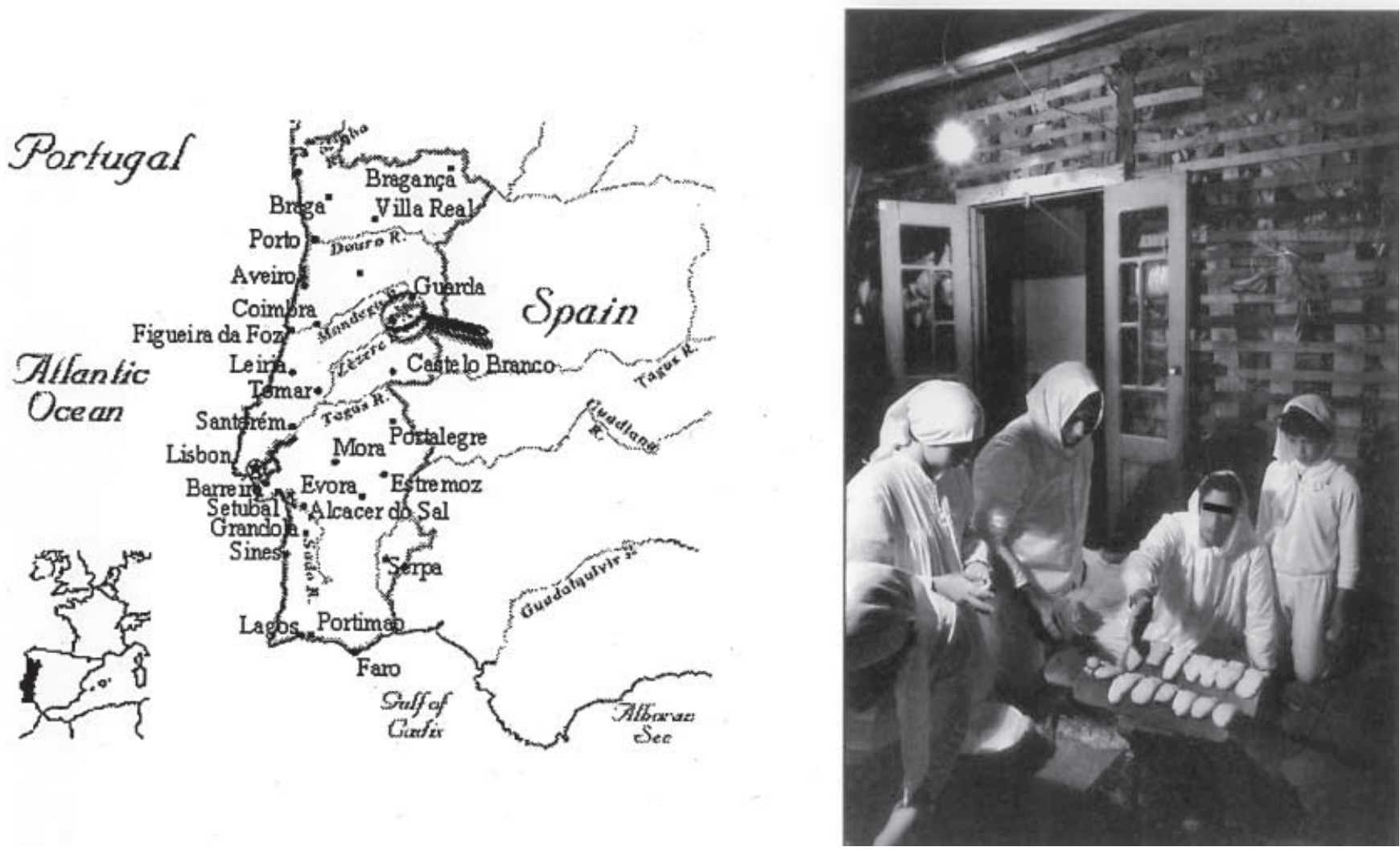

Fig. 1 A Map of Portugal showing the mountainous village of Belmonte in the Beira-Baixa province. B Secret preparation of Passover (Pessah): clandestine making of unleavened bread (Matza) in cellar

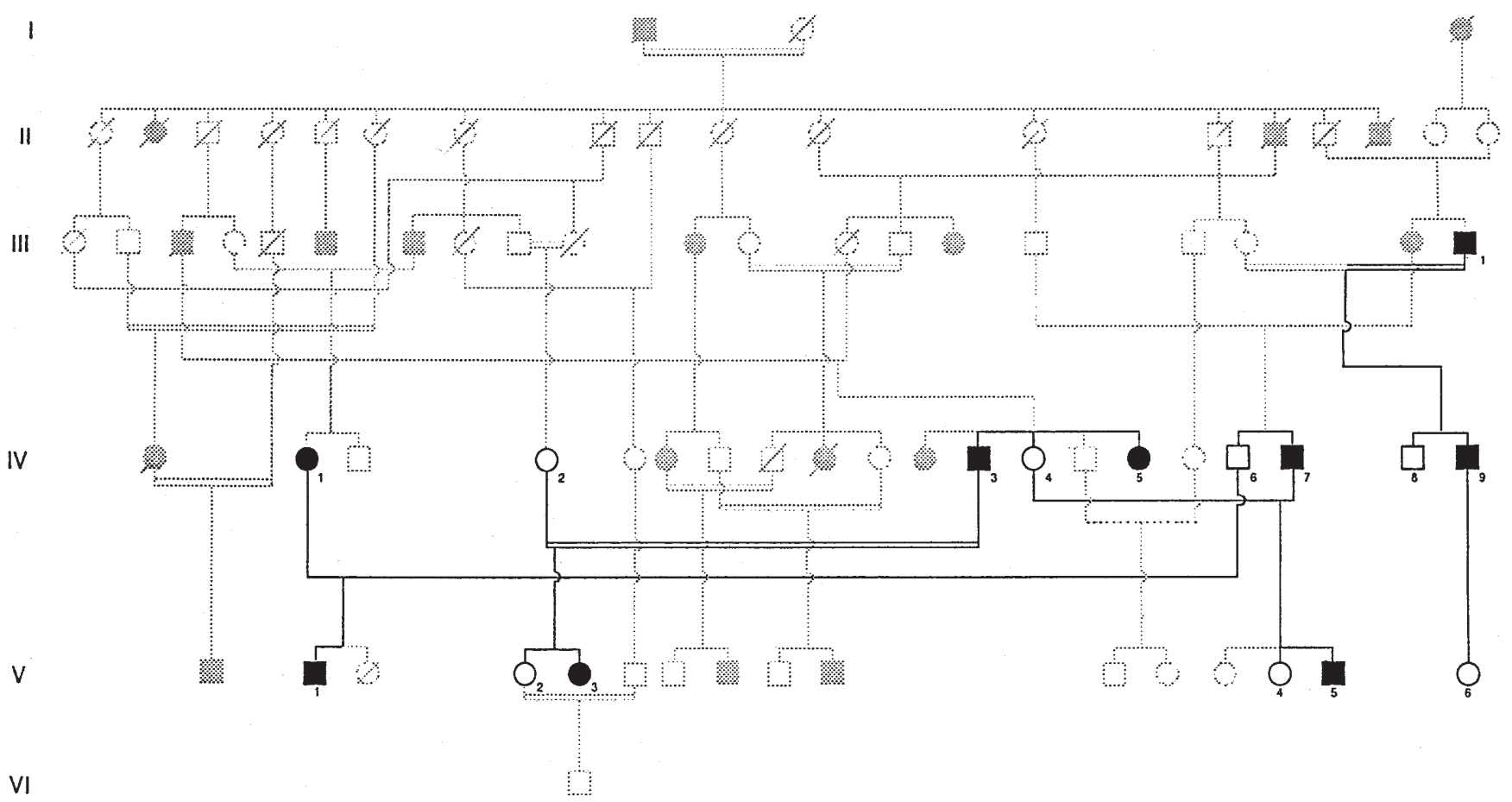

Fig. 2 Pedigree of the Belmonte family. The solid and open symbols represent affected and unaffected individuals, respectively. Individuals included in this study are shown in bold 
herited human diseases in which retinal degeneration leads to visual loss and eventually to blindness. Many diseasecausing mutations have been shown to involve genes encoding rod outer segment proteins (for a review, see Dryja and Li 1995) but many more RP genes have yet to be identified.

\section{Materials and methods}

Patients

A highly consanguineous population affected with autosomal recessive RP (Fig. 2) was ascertained through the Ophthalmologic Consultation of the Dos Capuchos Hospital of Lisboa. All family members underwent general and ophthalmologic examinations. Each patient's blood was collected in Belmonte and brought back to France for analysis.

Four markers containing short tracks of $(\mathrm{CA})_{\mathrm{n}}$ repeats and flanking each of the thirteen RP loci studied were chosen from the Généthon Linkage Map (Dib et al. 1996) on the basis of their informativity (not shown, available on request). On the other hand, a genome-wide search for homozygosity was undertaken in nine RP patients (Fig. 4) with the 382 pairs of fluorescent oligonucleotides of the Genescan Linkage Mapping Set, Version II (Perkin Elmer Cetus) under conditions recommended by the manufacturer. Amplified fragments were electrophoresed and analyzed on an automatic sequencer (ABI 377). The polymorphic markers have an average spacing of $10 \mathrm{cM}$ throughout the genome. Linkage analyses were performed using M-LINK and LINKMAP of the 5.1 version of the Linkage program (Lathrop and Lalouel 1984; Lander and Bolstein 1987).

\section{Fluorescence in situ hybridization}

For fluorescence in situ hybridization (FISH), elongated chromosomes from a healthy donor were obtained from lymphocyte synchronized culture. The YAC $960 \mathrm{~b} 6$ was used as a probe to determine the chromosome localization of the photoreceptor cell-specific nuclear receptor $(P N R)$ gene. The YAC DNA was amplified by Alu-PCR reaction and labeled with FITC-dUTP (Roche) by nick translation. Normal metaphase chromosomes were hybridized using $10 \mathrm{ng} / \mathrm{ml}$ of labeled probe for $24 \mathrm{~h}$ and the signal was analyzed on an epifluorescent microscope (Leica) with the QFISH vysis software. Ten mitoses were analyzed to determine the probe localization.

Mutation screening of SLC24A1

The ten exons encoding the retinal rod $\mathrm{Na}-\mathrm{Ca}-\mathrm{K}$ exchanger gene (SLC24A1) were amplified and sequenced using specific primers designed from the intronic sequences nearby the intron-exon junctions (data not shown, available on request).

\section{Mutation screening of $P N R$}

The PNR gene (200 ng genomic DNA) of patient IV-9 (Fig. 2) was amplified in two overlapping fragments (F1: 2700 bp and F2: 4360 bp) with specific primers designed from the cDNA sequence (P1$\mathrm{P} 2, \mathrm{P} 3-\mathrm{P} 4$, respectively) in a buffer $(15 \mu \mathrm{l})$ containing $50 \mathrm{mM}$ Tris$\mathrm{HCl}(\mathrm{pH} 9.2), 16 \mathrm{mM}\left(\mathrm{NH}_{4}\right)_{2} \mathrm{SO}_{4}, 2.25 \mathrm{mM} \mathrm{MgCl}_{2}, 2 \%$ (v/v) DMSO, $1 \%(\mathrm{v} / \mathrm{v})$ Tween, $400 \mu \mathrm{M}$ of each dNTP, $400 \mathrm{nM}$ of each primer and $1.5 \mathrm{U}$ of Taq DNA-Pwo DNA polymerase (Expand Template PCR System, Roche). After an initial denaturation for $5 \mathrm{~min}$ at $94^{\circ} \mathrm{C}$, denaturation was at $93^{\circ} \mathrm{C}$ for $10 \mathrm{~s}$ and annealing/extension were at $65^{\circ} \mathrm{C}$ for $3 \mathrm{~min}$, for 30 cycles followed by a final extension, for $7 \mathrm{~min}$ at $68^{\circ} \mathrm{C}$.

Amplified products were loaded onto a $1 \%$ agarose gel, purified by phenol-chloroform extraction and recovered by ethanol precipitation. Purified fragments were directly sequenced using specific primers designed from the cDNA sequence: P1-P3, P5-P8 for fragment F1; and P3, P4, P9, P10 for fragment F2.

Oligonucleotide sequences (forward/reverse, 5'-3') of the $P N R$ gene were as follows: P1 (5'-GCCAGGCTCAGCAACCCAGG$\left.3^{\prime}\right)$; P2 (5'-GGCTTGAAGAGGACCAAGG-3'); P3 (5'-CCTGCTGGAAGAGGCGTGG-3'); P4 (5'-CACCTACGAGGAATTGCTGG-3'); P5 (5'-CCTGCAGGCACTTCTTCAGC-3'); P6 (5'CTTAGCACAGGTTTCAGCTG-3'); P7 (5'-CCTGCGGCCTGGACAGCATC-3'); P8 (5'-GCCATGAAGAGTAGGCGAGC-3'); P9 (5'-GGATCCTGAGCACGTAGAG-3'); P10 (5'-CTGGCTCAGCATCACTTGG-3')

For screening the G1020A PNR mutation in the Crypto-Jews and in the general population, genomic DNA (200 ng) of all patients and relatives, as well as 192 controls of various ethnic origins, was submitted to PCR amplification using $1 \mu \mathrm{M}$ of primers $\mathrm{P} 2, \mathrm{P} 3$ and $\alpha\left[{ }^{33} \mathrm{P}\right] \mathrm{dCTP}(0.07 \mu \mathrm{l}, 10 \mathrm{mCi} / \mathrm{ml}$; NEN $)$ in an amplification mixture $(20 \mu \mathrm{l})$ containing $200 \mu \mathrm{M}$ dNTPs and $0.5 \mathrm{U}$ Taq DNA polymerase (Life-Technologies). Amplified DNA (6 $\mu \mathrm{l})$ was mixed with an equal volume of formamide loading dye $(95 \%$ formamide, $20 \mathrm{mM}$ EDTA, $0.05 \%$ bromophenol blue, $0.05 \%$ xylene cyanol), denatured for $10 \mathrm{~min}$ at $95^{\circ} \mathrm{C}$, loaded onto a polyacrylamide gel $(30 \times 40 \times 0.04 \mathrm{~cm} \mathrm{MDE}, \mathrm{TEBU})$ and electrophoresed at room temperature for $14 \mathrm{~h}$ at $4 \mathrm{~W}$. Gels were transferred onto 3 MM Whatman paper, dried and autoradiographed with Kodak BIOMAX-MR films for $16-48 \mathrm{~h}$.

\section{Plasmid construction}

The VP-PNR construct was obtained by inserting the full length human PNR cDNA ( $h P N R$ ) into pVP-16 (Clontech). The GAL4PNR construct was obtained by inserting the $h P N R$ ligand binding domain (LBD) into pCMX-GAL4. The $h P N R$ coding sequences used above were obtained by PCR amplification from pMOShPNR (Kobayashi et al. 1999). Primers used were: 5' (5'-GCGAATTCATGGAGACCAGACCAAACGCTCTC-3') and 3' (5'GCGTCGACCTAGTTTTTGAACATATCACAAAG-3') for VPPNR; 5' (5'-AGCTGAATTCATGAACCAGGACGCCGTGCA3') and 3' (5'-GTAATACGACTCACTATAGGGC-3') for GAL4PNR. To prepare $P N R$ mutant constructs, VP-PNR was used as a template for 12 cycles of PCR with the following primers : $5^{\prime}\left(5^{\prime}\right.$ CTATCTCTCGGTTCCAGGCATTGGCGGTG-3') and 3' (5'-CACCGCCAATGCCTGGAACCGAGAGATAG-3'); the DNA was digested with $D p n I$ and transformed to select for positive colonies. GAL4 mutants were derived from the VP-PNR R311Q construct. The PNRE-tk-luc reporter was constructed by insertion of the following double-stranded oligonucleotide primer (5'-AAGTCAAAAGTCAACTAAAAGTCAAAAGTCA-3') into tk-luc (Glass et al. 1989). All constructs were confirmed by sequencing.

\section{Transactivation assays}

Human embryonic kidney 293 T cells were used for transfection assays in 24-well cluster tissue culture plates with Lipofectin Reagent (Life Technologies). Transfection mixtures contained the indicated concentrations of plasmid, $500 \mathrm{ng}$ tk-luc reporter and $5 \mathrm{ng}$ pRL-CMV vector (Promega) as control for transfection efficiency. For the mammalian two-hybrid assay (Forman et al. 1995), transfection mixtures contained $100 \mathrm{ng}$ GAL-fusion plasmids, $100 \mathrm{ng}$ VP-fusion plasmids, $500 \mathrm{ng}$ MH100-tk-luc reporter plasmids and $5 \mathrm{ng}$ of pRL-CMV vector (Promega). Cells were transfected for $4 \mathrm{~h}$, incubated for $36 \mathrm{~h}$ in DMEM containing 10\% FBS prior to harvesting and assaying for luciferase activity with the Dual-Luciferase TM Reporter Assay System (Promega). The values were first measured for luciferase activity in relative light units, then normalized against the beta-galactosidase used as an internal control for transfection activity. The interaction between the wild-type PNR (VP and GAL) was taken as $100 \%$ and all other values were calculated correspondingly. All experimental determinations were performed in triplicate and repeated at least twice 
during independent experiments with variations of less than $10 \%$.

Dating the founder mutation

The G1020A mutation occurred in an ancestor haplotype that could be reconstructed by comparing the distinct pedigree haplotypes. For any generation number $(g)$ elapsed since the occurrence of the mutation (i.e., the earliest common ancestor), the probability of observing the remaining original haplotype on one side of a mutation in a given interval $(t)$ can be directly calculated as (1-t) (Blumberg and Evans 1998). The likelihood of any generation number is computed following Bayes theorem by dividing each of these probabilities by the sum of all probabilities (Hästbacka et al. 1992; Piccolo et al. 1996).

\section{Results}

\section{Clinical features of RP}

The clinical history of RP starts within the first decade with night blindness, followed during the second and the

Fig. 3 A Fundus of IV3. Note the typical aspect of retinitis pigmentosa with pigmentary spicules, very thin vessels and chorioretinal atrophy. B Tubular visual field of IV3 third decades by a slow concentric reduction of the visual field. Visual acuity decreases around 40 years of age, but the affected individuals are not completely blind even when elderly. The fundus shows typical features of RP i.e., pigment deposits in the peripheral retina, retinal pigment epithelium (RPE) atrophy, and waxy pallor of the optic nerve. The visual field measurement shows concentric reduction leading to tubular visual field (Fig. 3). The electroretinogram is severely reduced in the first stages and is not recordable at advanced stages. No associated symptoms, such as deafness, obesity, mental retardation, hypogonadism, renal failure or hexadactyly, were noted.

\section{Primary mapping of the RP-causing gene}

We first excluded the thirteen loci already known to account for autosomal recessive RP, i.e., RHO, PDE6B, PDE6A, RLBP1, RP12, TULP1, CNGA1, ABCR, RPE65, RP22, RP25, RP26, SAG (Genatlas: http://www.citi2.fr/ GENATLAS/welcome.html). Subsequently, a genome-wide search for homozygosity was undertaken and a total of 382 polymorphic markers were tested in this pedigree. We found evidence of homozygosity at the D15S131 locus in all nine affected individuals. The shortest area of homozy-

A
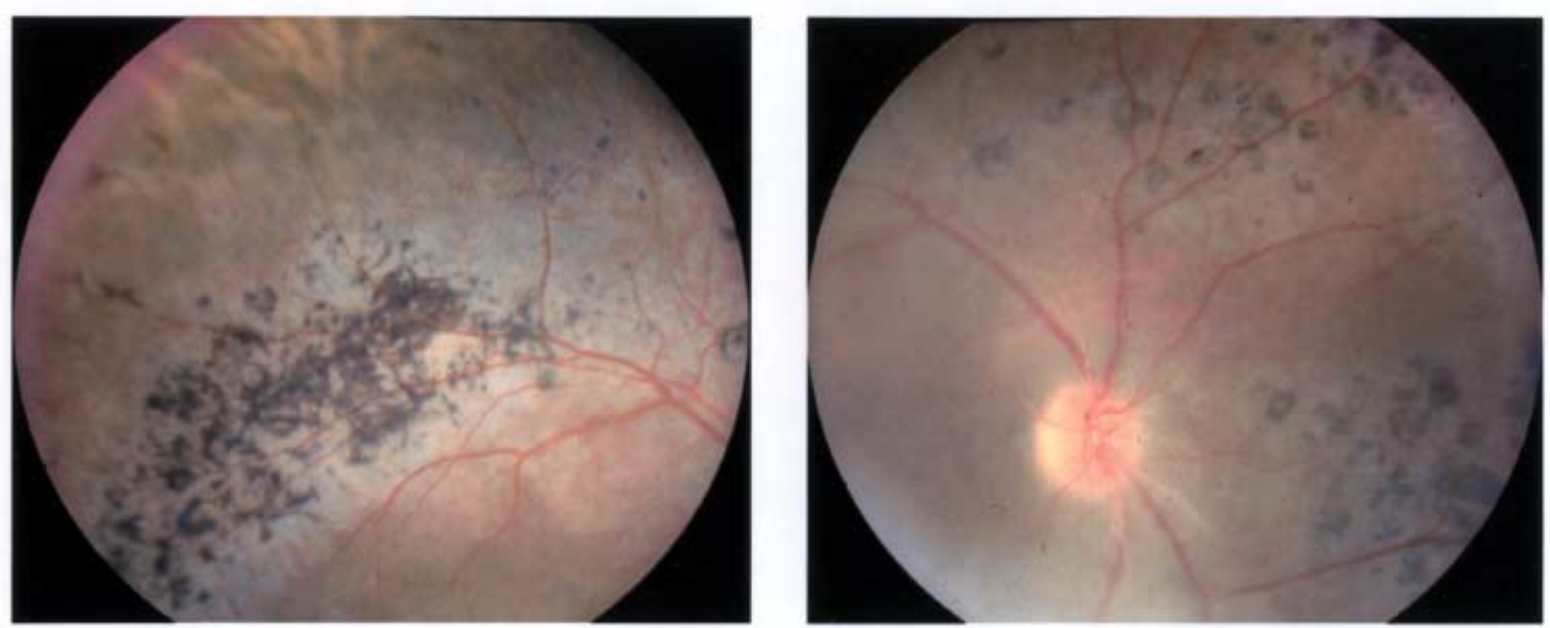

B
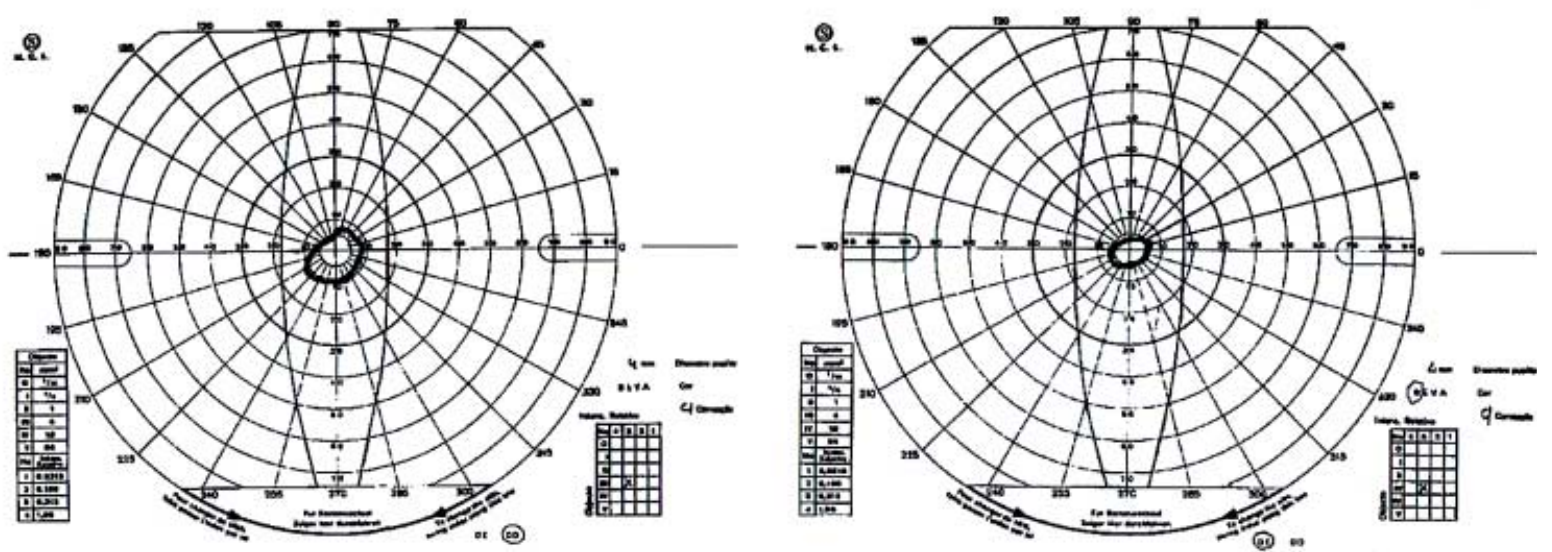


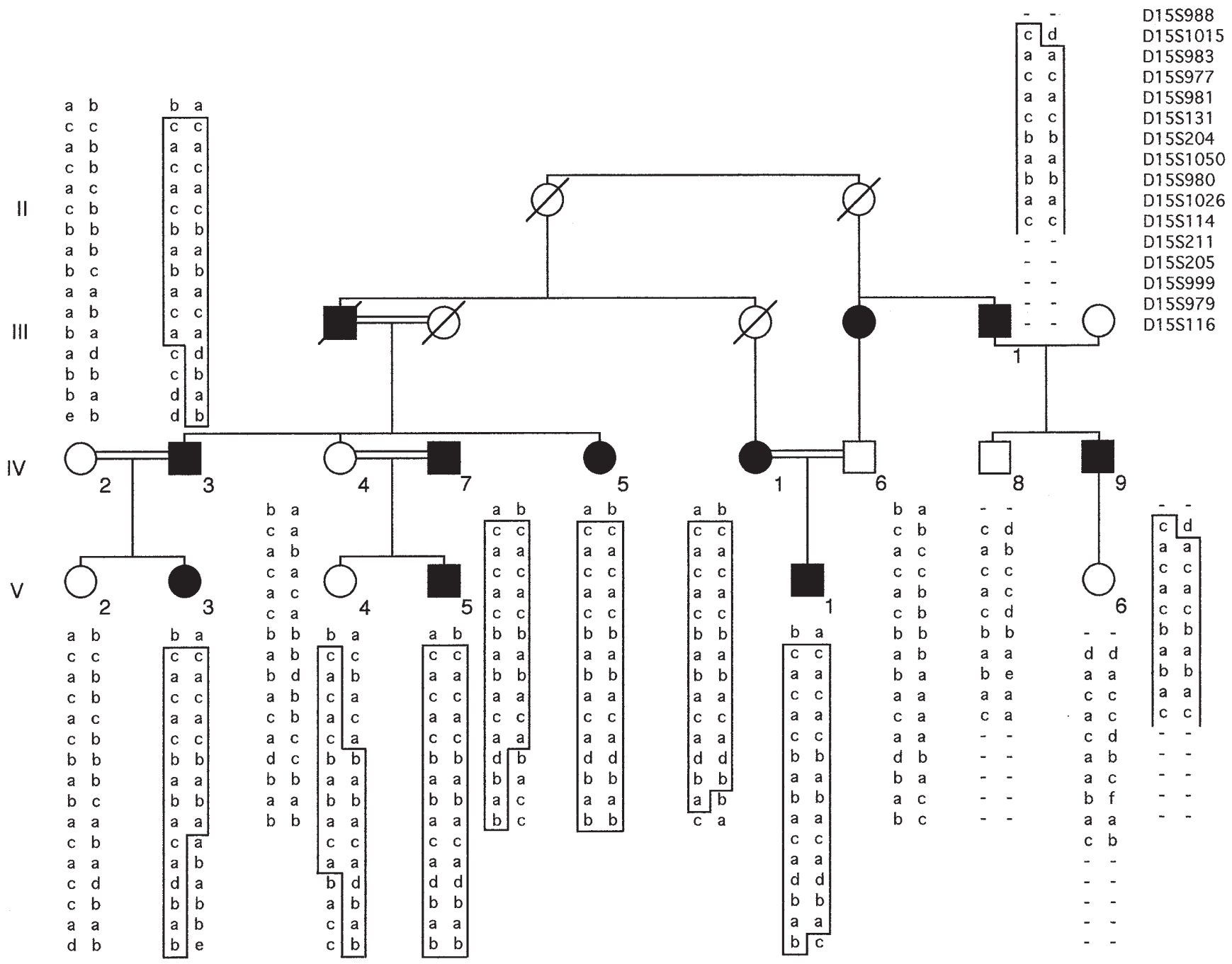

Fig. 4 Haplotype of the Belmonte family at the 15q22-q24 region

gosity is defined by the D15S983-D15S1026 interval, but recombination events in an healthy woman (V4) supported placement of the disease gene in the $5.4 \mathrm{cM}$ interval defined by loci D15S1015 and D15S204 (Fig. 4). The maximal pairwise lod score was obtained at the D15S131 locus $(\mathrm{Zmax}=2.95$ at $\theta=0)$. It is worth noting that, due to the high level of consanguinity, and despite the number of meioses, a relatively low score value was obtained. Finally, no other homozygous region was found using the remaining markers tested.

\section{Identification of the RP-causing gene}

The SLC24A1 gene has been recently mapped to chromosome $15 \mathrm{q} 22$ between markers D15S125 and D15S216 (Tucker et al. 1998), an interval which overlaps the genetic interval encompassing the RP locus. A search for mutations was undertaken in our nine patients using direct sequencing and no deleterious change was found in any of the ten exons nor in any of the nine exon-intron boundaries of the gene allowing us to exclude the SLC24Al gene.

Starting from the flanking markers, D15S1015 and D15S204, seven YAC clones were ordered on chromosome 15q22-q24 using ESTs and STSs of the region (Fig. $5 \mathrm{~A})$. Interestingly, the PNR gene encoding the photoreceptor cell-specific nuclear receptor, localized on chromosome 15q24 (Kobayashi et al. 1999), was found to map to YAC 960 b6 (Fig. 5A). Using the YAC $960 \mathrm{~b} 6$ probe, FISH unambiguously showed spots on chromosome $15 \mathrm{q} 23$ in $80 \%$ of R-banding metaphases, allowing us to refine the previous physical mapping of the $P N R$ gene from $15 \mathrm{q} 24$ to $15 \mathrm{q} 23$ (Fig. 5B). We therefore regarded $P N R$ as an attractive candidate gene by both position and function. The genomic structure of the PNR gene is unknown but the sequence of the human cDNA and the position of the introns have been reported (GenBank accession no. AF121129). The entire $P N R$ gene was amplified in two overlapping fragments using specific primers designed from the cDNA sequence. A search for mutations was undertaken for the nine available patients by direct sequencing. All patients tested were found to carry a homozygous mis- 


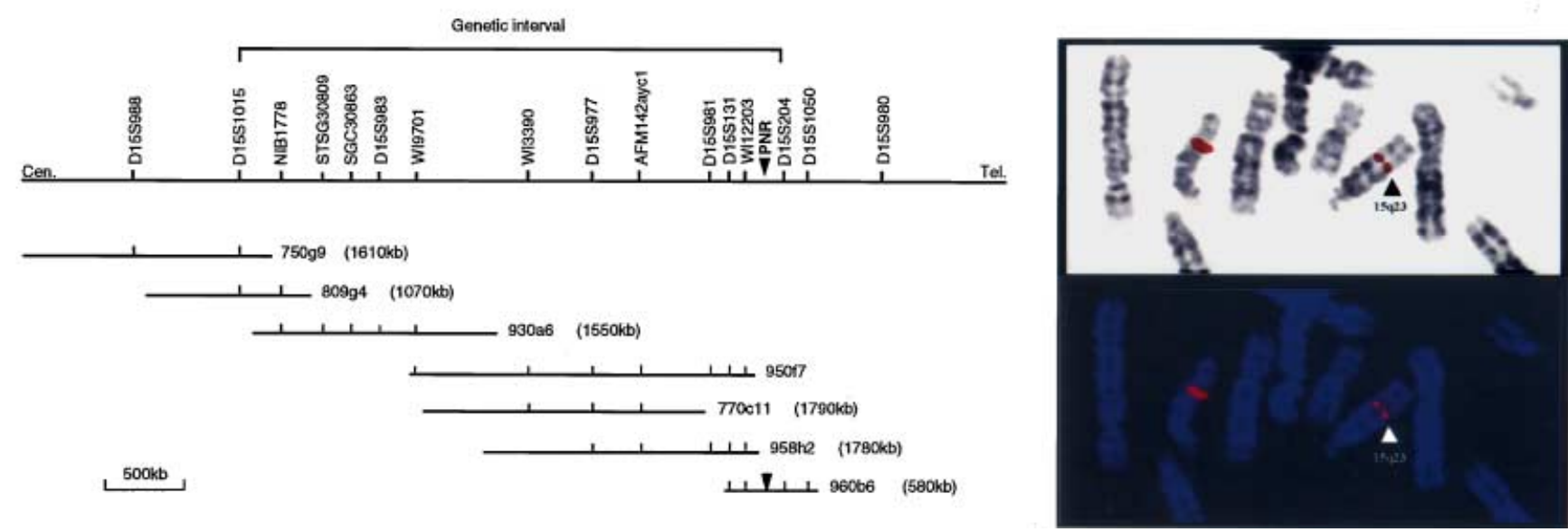

Fig.5 A YAC contig encompassing the gene responsible for RP in the Belmonte population at the 15q22-q24 locus. B Refining of PNR localization by FISH: the red signal corresponds to the hybridization of the YAC $960 \mathrm{~b} 6$ on the $15 \mathrm{q} 23$ band

sense mutation in exon 6 at nucleotide 1020 (G1020A, Fig. 6). This mutation changed an arginine into a glutamine in the protein (R311Q). This base change caused an abnormal SSCP pattern of migration that segregated with the disease in the entire pedigree and was absent in 192 controls of various ethnic origins.

Functional analyses

The region affected by the mutation is known to be involved in dimerization of nuclear receptor members (for review, see Mangelsdorf et al. 1995), and the formation of homodimers by PNR is regarded as essential for its DNA binding function (Kobayashi et al. 1999). By means of the mammalian two-hybrid technique (Forman et al. 1995), which utilizes chimeric receptors containing the yeast Gal4 DNA binding domain and a nuclear receptor ligand binding domain (LBD), we investigated how this single nucleotide change in the PNR LBD affected its function. The results clearly demonstrated that the R311Q mutation hinders the ability of PNR to form stable dimers (Fig. 7B). Interestingly, this mutation did not significantly alter the in vitro DNA binding capacities (not shown) nor the ability of PNR to repress transcription through its DNA response element upon overexpression in cultured cells (Fig. 7A).
Fig. 6 Identification of a homozygous missense mutation, G1020A, in exon 6 of the $P N R$ gene ( $C$ control, $P$ patient)
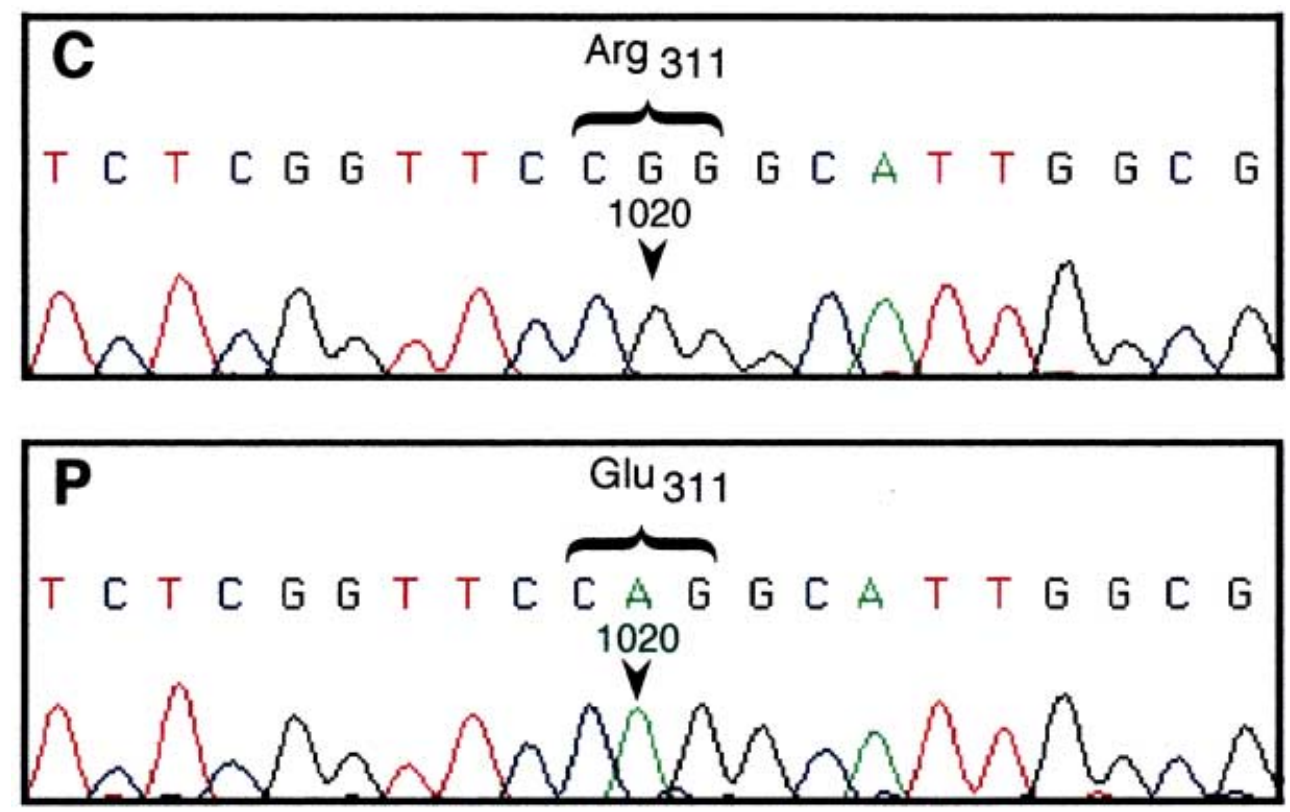


\section{A Transcriptional Repression}

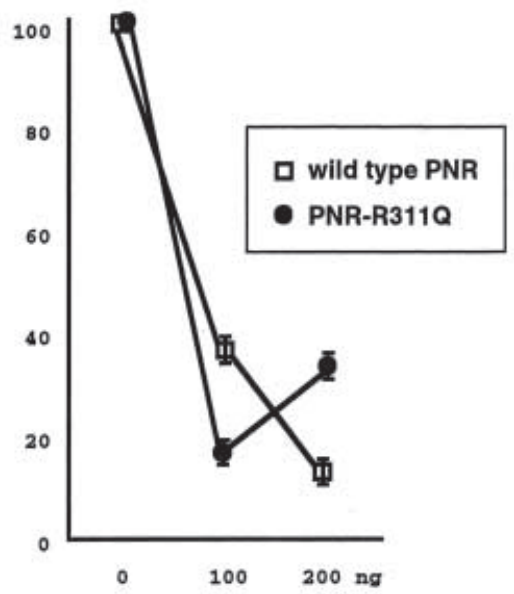

\section{B Dimerization}

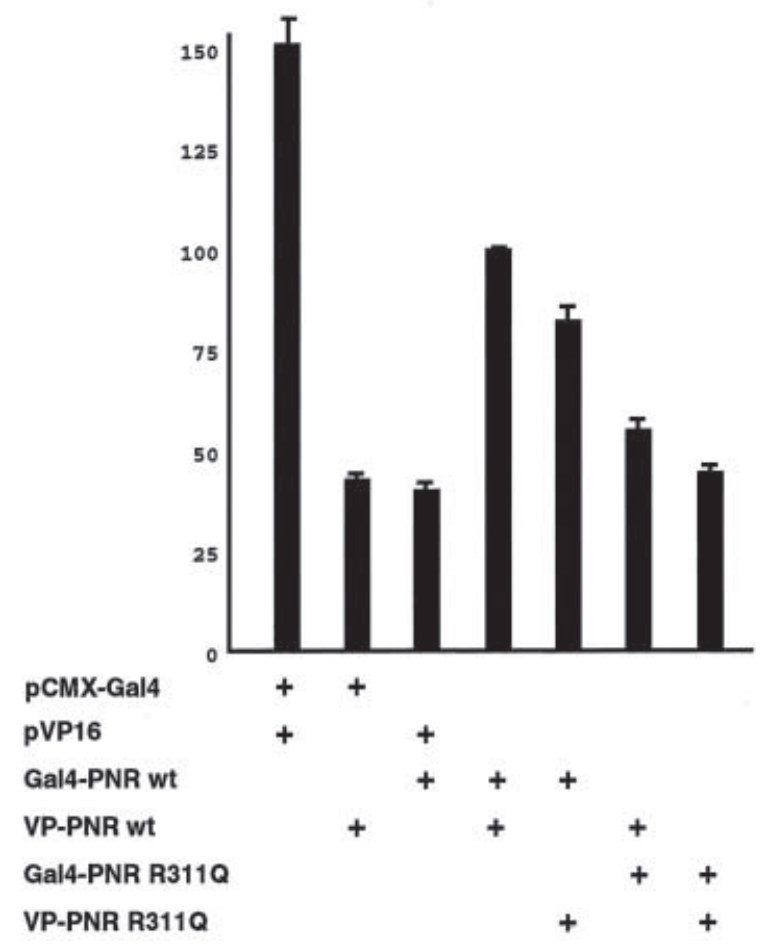

Fig. 7 Functional analyses of wild-type and mutant PNR proteins. A The G1020A mutation does not significantly affect the ability of PNR to repress reporter gene transcription. The $x$-axis shows the activity at two concentrations of PNR expression plasmid ( 0 , $100 \mathrm{ng}, 200 \mathrm{ng}$ ) and the $y$-axis, the fold activity. The 100 value was set at $0 \mathrm{ng}$ as a standard from which other values were calculated. Standard deviations (SD) for 100 and $200 \mathrm{ng}$ were 2.8 and 1.5 for the wild type and 1.8 and 2.4 for PNR-R311Q, respectively. B The effect of the mutation on the ability of the PNR LBD to dimerize was tested in the mammalian two-hybrid assay. Combinations of constructs used are as indicated. GAL4 and VP16, which are known to interact with high affinity, are shown as the positive control. The GAL4 and VP-PNR or VP16 and GAL-PNR, which should not interact, are shown for background interaction. Note the interaction between GAL-PNR wt with VP-PNR wt and the decrease in interaction with the mutant PNR. Starting from the left, SD were: $6,1.4,1.6,0$ (value set at 100 against which other values were calculated), 3.2, 2.1 and 1.5

\section{Mutation data}

Computation suggested that the most likely number of generations elapsed since the appearance of the mutation averages 15 (95\% confidence interval: 8-20, not shown). Assuming that one generation lasts 25 years, this would indicate that the G1020A mutation is ancient and occurred between 200 and 500 years ago.

\section{Discussion}

Here we report on the mapping of a new RP gene to chromosome $15 q 23$ in a large pedigree of Portuguese CryptoJews, the descendants of the Marranos who lived in Spain and Portugal in the 15 th century. Homozygosity mapping and key recombinant events allowed us to reduce the critical interval to a region of $5 \mathrm{cM}$ encompassing the $P N R$ gene and to eventually identify the disease-causing missense mutation in exon 6 of the gene. This genetic interval overlaps the chromosomal region in which the fourth gene responsible for Bardet-Biedl syndrome (BBS4) has been mapped (Carmi et al. 1995; Bruford et al. 1997). Yet, affected individuals of the Crypto-Jews population of Belmonte displayed no symptom of BBS, i.e., obesity, hypogonadism, mental retardation, renal cysts or polydactyly, raising the possibility of either two different RP genes within the same chromosomal region or, alternatively, various mutations in the same gene.

PNR is a member of a large family of ligand-dependent transcription factors which transduce inter- and intracellular lipophilic signals and contain DNA and ligand binding domains (Kobayashi et al. 1999). In recent years, many additional members of the family (the so-called orphan receptors) have been identified on the basis of these structural features, which in turn has provided tools to search for molecules acting as specific ligands in order to unravel novel signaling pathways (Enmark and Gustafsson 1996; Blumberg and Evans 1998). In vertebrates, the original member of this family, $T L X$, the homologue of the Drosophila tailless gene, shows a restricted pattern of expression in the developing fore/midbrain neuroepithelium, retina, and nasal epithelium (Yu et al. 1994; Monaghan et al. 1995).

Subsequently, by searching for other genes related to $T L X$, the human $P N R$ gene was identified. This gene is specifically expressed in the outer nuclear layer of the 
retina photoreceptor cells. PNR is capable of binding to a subset of TLX target sequences in vitro, suggesting that they may be involved in the regulation of an overlapping target gene network. Unlike TLX, however, which can bind to and repress target gene transcription as a monomer, PNR requires dimeric half-site sequences, and gelshift analyses have shown that it binds to DNA, most likely as a homodimer (Kobayashi et al. 1999). The results of our analyses of the mutation in the PNR gene indicate that the amino acid substitution in the LBD significantly hampers its ability to dimerize. However, in in vitro DNA binding and in transient transfection assays, the mutated PNR retained its ability to bind DNA, and to repress transcription. This likely reflects the result of the high levels of protein obtained from overexpression in the assays. In an in vivo situation, the amount of PNR may be limiting, and thus even slight impairments in function would result in a disease phenotype.

The identification of such a photoreceptor-restricted nuclear receptor implies its possible involvement in a signaling pathway regulating photoreceptor differentiation and/or maintenance, which may be mediated by lipophilic molecules acting as PNR ligands. Indeed, PNR is believed to play a major role in the photoreceptor cell-specific transcription cascade by suppressing genes whose expression is refractory to photoreceptor function (Kobayashi et al. 1999). Chen et al. (1999) recently reported the identification of a splice variant of human $P N R$, which they termed $R N R$, as it is expressed in the retinal pigment epithelium and Müller glial cells of the adult. They further showed the possible involvement of PNR in the regulation of the cellular retinaldehyde-binding protein (CRALBP), an important component of the visual cycle. Taken together, these findings strongly support the involvement of PNR in retinal diseases.

In fact, Haider et al. (2000) recently reported on mutations in the PNR gene of patients affected with the socalled enhanced $\mathrm{S}$ cone syndrome. This syndrome is not clinically defined as the degree of clinical heterogeneity is extremely large. Indeed, patients affected with the enhanced S-cone syndrome can be classified either with Goldmann-Favre syndrome or with other variable features including macular scarring, yellow flecks in the retina, pigmentary retinopathy, peripheral retinoschisis and cataracts. On the other hand, this syndrome is only defined by a severe dysfunction of $\mathrm{S}$ cones compared to the function of L/M cones. This feature can only be detected by a particular electroretinographic measurement, i.e., $\mathrm{S}$ cone testing. Surprisingly, among the 12 different mutations identified in the ESCS cohort of patients, the R311Q amino acid change, identified in 13/29 unrelated patients (44.8\%), represents the most frequent mutation. It would be very useful to know the exact phenotype of each of these 13 patients, as well as the phenotype of patients harboring different mutations in the PNR gene, in order to search for genotype-phenotype correlations. Most interestingly, very recently a deletion in the murine $P N R$ gene has been identified in the $r d 7$ mouse. The $r d 7$ mice display clinical signs of retinal degeneration from 12 months of age and mottled retinal pigment is observed from 16 months. It is worth noting that ERG measured between age 1-5 months were strictly normal. ERG measurement only showed alterations from age 16 months. At this stage, these electrical alterations were associated with attenuated reduction of the caliber of the retinal vessels and mottled retinal pigment indicating retinal degeneration, but no cystic change in the foveal region or vitreous degeneration was noted. The very late phenotype of the $r d 7$ mouse is quite identical to the very late RP affecting the Crypto-Jews of Belmonte.

It would be interesting to perform $\mathrm{S}$ cone testing in our RP patients but the Belmonte population is, for obvious historical reasons, extremely closed and it has been extremely difficult to collect blood samples in only some of all affected patients and relatives in order to perform this work.

Finally, ongoing haplotype studies, as well as Bayesian calculations (Hästbacka et al. 1992; Piccolo et al. 1996), suggest that this mutation probably occurred 200-500 years ago, i.e., after this population of Crypto-Jews settled in Belmonte.

Acknowledgements This work was supported by the Association Retina France.

\section{References}

Blumberg B, Evans RM (1998) Orphan nuclear receptors - new ligands and new possibilities. Genes Dev 12:3149-3155

Bruford EA, Riise R, Teague PW, Porter K, Thomson KL, Moore AT, Jay M, et al (1997) Linkage mapping in 29 Bardet-Biedl syndrome families confirms loci in chromosomal regions 11q13, 15q22.3-q23, and 16q21. Genomics 41:93-99

Carmi R, Rokhlina T, Kwitek-Black AE, Elbedour K, Nishimura D, Stone EM, Sheffield VC (1995) Use of a DNA pooling strategy to identify a human obesity syndrome locus on chromosome 15. Hum Mol Genet 4:9-13

Chen F, Figueroa DJ, Marmorstein AD, Zhang Q, Pertrukhin K, Caskey CT, Austin CP (1999) Retina-specific nuclear receptor: a potential regulator of cellular retinaldehyde-binding protein expressed in retinal pigment epithelium and Müller glial cells. Proc Natl Acad Sci USA 96:15149-15154

Dib C, Faure S, Fizames C, Samson D, Drouot N, Vignal A, MillasseauP, et al (1996) A comprehensive genetic map of the human genome based on 5264 microsatellites. Nature 380:152154

Dryja TP, Li T (1995) Molecular genetics of retinitis pigmentosa. Hum Mol Genet 4:1739-1743

Enmark E, Gustafsson JA (1996) Orphan nuclear receptors - the first eight years. Mol Endocrinol 10:1293-1307

Forman BM, Umesono K, Chen J, Evans RM (1995) Unique response pathways are established by allosteric interactions among nuclear hormone receptors. Cell 81:541-550

Glass CK, Lipkin SM, Devary OV, Rosenfeld MG (1989) Positive and negative regulation of gene transcription by a retinoic acidthyroid hormone receptor heterodimer. Cell 59:697-708

Haider NB, Jacobson SG, Cideciyan AV, Swiderski R, Streb LM, Searby C, Beck G, et al (2000) Mutation of a nuclear receptor gene, $N R 2 E 3$, causes enhanced $\mathrm{S}$ cone syndrome, a disorder of retinal cell fate. Nat Genet 24:127-131

Hästbacka J, de la Chapelle A, Kaitila I, Sistonen P, Weaver A, Lander E (1992) Linkage disequilibrium mapping in isolated founder populations: diastrophic dysplasia in Finland. Nat Genet 2:204-211 
Kobayashi M, Takezawa SI, Hara K, Yu RT, Umesono Y, Agata K, Taniwaki M, et al (1999) Identification of a photoreceptor cell-specific nuclear receptor. Proc Natl Acad Sci USA 96: 4814-4817

Lander ES, Bolstein D (1987) Homozygosity mapping: a way to map human recessive traits with the DNA of inbred children. Science 236:1567-1570

Lathrop GM, Lalouel JM (1984) Easy calculation of lod score and genetic risks on small computers. Am J Hum Genet 36:460465

Mangelsdorf DJ, Thummel C, Beato M, Herrlich P, Schutz G, Umesono K, Blumberg B, Kastner P, Mark M, Chambon P, Evans RM (1995) The nuclear receptor superfamily: the second decade. Cell 83:835-839

Monaghan AP, Grau E, Bock D, Schütz G (1995) The mouse homolog of the orphan nuclear receptor tailless is expressed in the developing forebrain. Development 121:839-853
Piccolo F, Jeanpierre M, Leturcq F, Dode C, Azibi K, Toutain A, Merlini L, et al (1996) A founder mutation in the gamma sarcoglycan gene of Gypsies possibly predating their migration out of India. Hum Mol Genet 5:2019-2022

Tucker IE, WinkfeinRJ, Murthy SK, Friedman JS, Walter MA, Demetrick DJ, Schnetkamp PP (1998) Chromosomal localization and genomic organization of the human retinal rod $\mathrm{Na}-$ $\mathrm{Ca}+\mathrm{K}$ exchanger. Hum Genet 103:411-414

Yerushalmi YH (1992) Les derniers Marranes, le temps, la peur, la mémoire. In: Yerushalmi YH (ed) Marranes. La Différence pp $19-44$

Yu RT, McKeown M, Evans RM, Umesono K (1994) Relationship between Drosophila gap gene tailless and vertebrate nuclear receptor TLX. Nature 370:375-379 